\title{
Penambahan Daging Ayam pada Pembuatan Abon Ampas Kelapa (Cocos Nucifera L.)
}

\author{
Hamka \\ Program Studi Teknologi Hasil Perkebunan, \\ Politeknik Pertanian Negeri Samarinda-Indonesia 75131 \\ hamka@politanisamarinda.ac.id
}

\author{
Asmina Sunriyani Raten \\ Program Studi Teknologi Hasil \\ Perkebunan, Politeknik Pertanian \\ Negeri Samarinda-Indonesia 75131 \\ hamka@politanisamarinda.ac.id
}

\author{
Marwati \\ Prodi Teknologi Hasil Pertanian, \\ Universitas Mulawarman-Indonesia \\ 75123 \\ marwatiwawa.unmul@gmail.com \\ Husmul Beze \\ Program Studi Teknologi Rekayasa \\ Perangkat Lunak, Politeknik \\ Pertanian Negeri Samarinda- \\ Indonesia 75131 \\ hamka@politanisamarinda.ac.id
}

\author{
Heriad Daud Salusu \\ Program Studi Pengolahan Hasil \\ Hutan, Politeknik Pertanian Negeri \\ Samarinda- Indonesia 75131 \\ hamka@politanisamarinda.ac.id
}

\author{
Eva Nurmarini \\ Program Studi Rekayasa Kayu, \\ Politeknik Pertanian Negeri \\ Samarinda-Indonesia 75131 \\ hamka@politanisamarinda.ac.id
}

\author{
Yulianto \\ Program Studi Teknologi Rekayasa \\ Perangkat Lunak, Politeknik \\ Pertanian Negeri Samarinda- \\ Indonesia 75131 \\ hamka@politanisamarinda.ac.id
}

\begin{abstract}
Abstrak - Tujuan penelitian ini adalah untuk mengetahui karakteristik kimia berupa uji kadar air, kadar abu, kadar protein, kadar lemak dan karbohidrat dan organoleptik tingkat kesukaan panelis terhadap warna, aroma, rasa dan tekstur dari abon ampas kelapa yang ditambahkan daging ayam.Penelitian ini menggunakan rancangan acak lengkap (RAL) dengan penambahan ampas kelapa dan daging ayam yang terdiri dari 4 perlakuan dan setiap perlakuan di ulang sebanyak 3 (tiga) kali. Parameter yang diamati pada penelitian ini adalah Uji kadar air, kadar abu, kadar protein, kadar lemak, karbohidrat dan organoleptik yang terdiri dari warna, aroma, rasa dan tekstur. Adapun perlakuan pembuatan abon ampas kelapa yakni perlakuan ampas kelapa 0 gram dan daging ayam 350 gram, ampas kelapa 100 gram daging 250 gram, ampas kelapa 200 gram daging ayam 150 gram dan ampas kelapa 300 gram daging ayam 50 gram. Hasil penelitian menunjukan Hasil uji kimia pembuatan abon menggunakan ampas kelapa sebagai bahan pengisi memiliki kandungan air yang tinggi pada perlakuan dengan daging ayam 350 gram dan ampas kelapa 0 gram dengan nilai kadar air $13.07 \%$ tidak sesuai syarat mutu SNI abon. Kadar abu dan kadar lemak yang tertinggi pada perlakuan dengan daging ayam 50 gram dan ampas kelapa 300 gram dengan nilai $2.79 \%$ dan $40,64 \%$. sementara kadar protein dan karbohidrat yang tertinggi pada perlakuan dengan daging ayam 0 gram dan ampas kelapa 350 gram dengan nilai rata-rata $25.63 \%$ dan $47,97 \%$. Hasil uji organoleptik terhadap pembuatan abon menggunakan ampas kelapa sebagai bahan pengisi dengan penambahan daging ayam memperlihatkan bahwa warna, aroma, rasa dan tekstur terhadap kesukaan panelis menunjukan angka suka yaitu dengan rata - rata nilai tertinggi pada perlakuan dengan daging ayam 150 gram dan ampas kelapa 200 gram dengan nilai rata-rata 3.61 (suka), aroma 3.80 (suka), rasa 3.67(suka) dan pada tekstur 3.85(suka).
\end{abstract}

Kata kunci: abon, ampas kelapa, daging ayam, uji kimia, uji organoleptik

\section{PENDAhuluan}

Indonesia memiliki potensi sumber daya alam yang melimpah, salah satunya adalah bidang pertanian. komoditas perkebunan yang menjadi primadona selain sawit adalah kelapa. Kelapa merupakan buah yang memiliki banyak manfaat dalam industri pengolahan pangan. Beberapa produk dari kelapa seperti, minyak goreng, santan, virgin coconut oil (VCO), dan lain-lain. Semua produk tersebut olahan kelapa tersebut di dalam pengolahannya menghasilkan limbah yaitu ampas kelapa. Saat ini di Politeknik Pertanian Negeri Samarinda (Politani Samarinda di Laboratorium Pengolahan Hasil Perkebunan dikembangkan industri pembuatan VCO. Dari setiap pengolahan VCO, limbah ampas kelapa menjadi bahan yang belum termanfaatkan. Ampas kelapa sebagai limbah dari VCO masih memiliki kandungan gizi yaitu protein $(5,78 \%)$, lemak $(38,24 \%)$, serat kasar $(15,07 \%)$, galaktomanan $(61 \%)$, manan $(26 \%)$, selulosa (16\%), karbohidrat $(93 \%)$ dan air $(6,02 \%)$ (Pravitasari, 2017). Pemanfaatan ampas kelapa masih sangat terbatas, misalnya untuk pakan ternak dan sebagian dijadikan tempe bongkrek untuk makanan (Hutsoit, 1988). Ampas kelapa dapat diolah menjadi tepung dan bisa digunakan sebagai bahan dalam pembuatan produk pangan seperti abon. Pengolahan ampas kelapa menjadi abon juga bertujuan untuk meningkatkan nilai ekonomis. Tujuan jangka panjang dan target khusus yang ingin dicapai yaitu pembuatan abon yang dapat diaplikasikan oleh masyarakat untuk menghasilkan suatu produk berupa abon ampas kelapa sebagai produk pangan atau sebagai bahan pangan pendamping yang kaya akan serat. 
Pada penelitian ini abon ampas kelapa akan diformulasikan dengan penambahan daging ayam.

\section{METODOLOGI}

\section{A. Bahan dan Alat}

Bahan yang digunakan dalam penelitian ini adalah ampas kelapa, daging ayam, garam, gula, minyak goreng, dan rempah. Sementara alat yang digunakan yaitu timbangan, pisau, panci, talenan, kompor, sendok, sutil, baskom, wajan, blender serta alat tulis dan alat dokumentasi.

\section{B. Metode Penelitian}

Metode penelitian yang digunakan adalah perhitungan rata-rata. penelitian ini dilaksanakan menggunakan perlakuan dengan ampas kelapa sebagai bahan pengisi yaitu perlakuan satu (P1) ampas kelapa 0 gram, dan daging ayam 350 gram, perlakuan dua (P2) ampas kelapa 100 gram, dan daging ayam 250 gram perlakuan tiga (P3) ampas kealap dan 200 gram dan daging ayam 150 gram, dan perlakuan empat (P4) ampas kelapa 300 gram dan daging ayam 50 gram. Masing masing perlakuan diulang sebanyak tiga kali, maka satuan percobaan yang digunakan adalah 4 x $3=12$ satuan percobaan. Parameter yang diamati meliputi kadar air, Kadar abu, kadar protein, kadar lemak, karbohidrat (Andarwulan, 2011) dan tingkat kesukaan dengan uji organoleptik (warna, aroma, rasa, dan tekstur) (Soekarto, 1985).

\section{Proses pembuatan abon ampas kelapa}

Adapun proses pembuatan abon menggunakan ampas kelapa sebagai bahan pengisi sebagai berikut:

1. Alat dan bahan disiapkan.

2. Daging ayam dan rempah dibersihkan dan dicuci dengan air bersih.

3. Kemudian Ampas kelapa dan daging ayam dikukus selama 30 menit.

4. Ampas kelapa dan daging ayam yang sudah dikukus didinginkan di udara terbuka.

5. Kemudian daging ayam disuir untuk dipisahkan dari tulang dan kulit.

6. Penimbangan ampas kelapa dan daging ayam sebanyak 0 gram : 350 gram perlakuan satu (P1), 100 gram : 250 gram perlakuan 2 (P2), 200 gram : 150 gram perlakuan $3(\mathrm{P} 3)$, dan 300 gram : 50 gram perlakuan empat (P4).
7. Ditimbang semuah rempah menggunakan timbangan digital.

8. Rempah-rempah seperti bawang putih, bawang merah, kemiri, serai dan lengkuas dihaluskan menggunakan blender selama 1 menit.

9. Ditumis rempah yang sudah diblender masukan daun salam, sampai wangi kemudian daging ayam yang sudah disuir dan ampas kelapa dimasukan secara berurutan.

10. Kemudian disangrai dalam wajan sampai menjadi abon selama 3 jam hingga kering dan warna kuning kecoklatan sampai tidak ada gumpalan.

11. Setelah itu dinginkan abon sampai benar-benar kering selama 20 menit.

12. Kemudian abon ampas kelapa siap untuk dikemas. 13. Abon ampas kelapa siap untuk dikonsumsi.

\section{HASIL DAN PEMBAHASAN}

\section{Uji Kimia Abon Ampas Kelapa}

Adapun hasil pengujian kimia pembuatan abon ampas kelapa dengan daging ayam sebagai bahan tambahan dapat dilihat dalam uji sebagai berikut.

\section{a. Kadar Air}

Hasil kadar air menunjukkan abon ampas kelapa dengan penambahan daging ayam yang telah diuji memiliki kadar air dari yang terendah sampai dengan yang tertinggi yaitu dari $9.92 \%-13.07 \%$. Dari gambar diatas dapat dilihat bahwa kadar air yang memiliki nilai terendah yaitu perlakuan dengan penambahan ampas kelapa 300 gram dan daging ayam 50 gram dengan lama pengeringan ampas kelapa 5 jam dapat menghasilkan kadar air dengan nilai $(9.92 \%)$. Namun tidak memenuhi persyaratan pembuatan abon jika merujuk pada Standar Nasional Indonesia (SNI) untuk kadar air abon yaitu maksimal 7\%. Hal ini dipengaruhi oleh adanya pengukusan yang bertujuan untuk menonaktifkan enzim lipase yang terdapat pada ampas kelapa dan komposisi air ampas kelapa dan daging ayam juga mempengaruhi terhadap nilai uji kadar air. Ampas kelapa kering dan daging ayam mengandung kadar air sebanyak 6,2\% (Pravitasari, 2017) dan 65,95\% (Stademan, 1988). Semakin banyak kadar air yang terkandung dalam suatu bahan pangan maka daya simpan bahan tersebut akan semakin singkat atau pendek. Pada proses pengeringan, air yang terkandung dalam bahan tidak dapat seluruhnya diuapkan. (Charistian, 1980). 


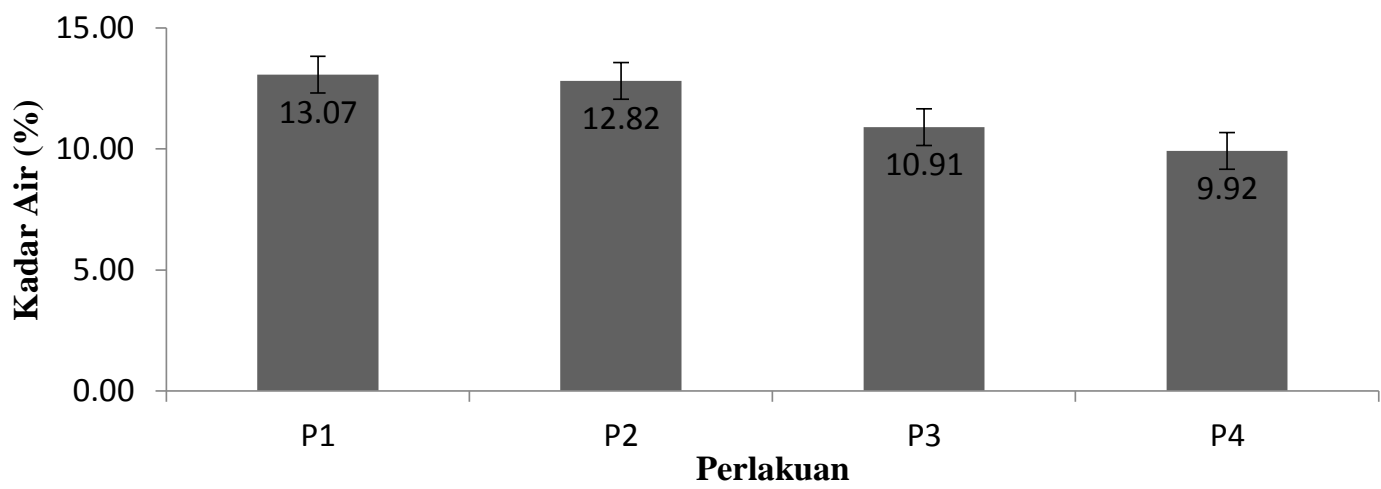

Keterangan:

$\mathrm{P} 1=$ Ampas kelapa 0 gram daging ayam 350 gram

$\mathrm{P} 2=$ Ampas kelapa 100 gram daging ayam 250 gram

P3 = Ampas kelapa 200 gram daging ayam 150 gram

P4 = Ampas kelapa 300 gram daging ayam 50 gram

Gambar 1. Hasil Uji kadar air pada pembuatan abon ampas kelapa dengan penambahan daging ayam

Berdasarkan uji BNT pada taraf uji $(\mathrm{P}>0,05)$ Terlihat bahwa uji kadar air pada perlakuan abon ampas kelapa dengan penambahan daging ayam berbeda tidak nyata pada taraf uji $(\mathrm{P}>0.05)$.

Tabel 1. Analisis Sidik Ragam Uji kadar air pada pembuatan abon ampas kelapa dengan penambahan daging ayam

\begin{tabular}{|c|c|c|c|c|c|}
\hline Sumber keragaman & $J K$ & $D B$ & $K T$ & F Hit & F Tabel \\
\hline Perlakuan & 20.73217348 & 3 & 6.910724 & $0.274734^{\mathrm{IIS}}$ & 4.066181 \\
\hline $\begin{array}{l}\text { Galat } \\
\text { Total }\end{array}$ & $\begin{array}{l}201.2340848 \\
221.9662582\end{array}$ & $\begin{array}{r}8 \\
11\end{array}$ & 25.15426 & & \\
\hline
\end{tabular}

\section{b. Kadar Abu}

Hasil uji kadar abu untuk abon ampas kelapa dengan penambahan daging ayam menunjukkan nilai antara 2,71-2,79\%. Nilai perlakuan tertinggi kadar abu pada perlakuan ampas kelapa 300 gram dan daging ayam 50 gram. Kadar abu suatu bahan erat kaitannya dengan kandungan mineral bahan baku. Mineral yang terdapat dalam suatu bahan berupa mineral garam organik dan garam anorganik. Dan untuk menentukan sisa-sisa pembakaran garam mineral dilakukan dengan pengabuan.
Semakin banyak penambahan ampas kelapa maka kadar abu abon ampas kelapa semakin tinggi. Hal tersebut menunjukan bahwa kadar abu pada ampas kelapa lebih tinggi dibandingkan dengan daging ayam. Menurut Rousmaliana dan Septiani (2019) kadar abu ampas kelapa adalah $0,34 \%$ (dalam bentuk tepung) sedangkan kadar abu daging ayam $0.79 \%$ (Stadelman et. al., 1988). Oleh karena itu semakin banyak penambahan ampas kelapa maka semakin tinggi jumlah rata-rata kadar abu.

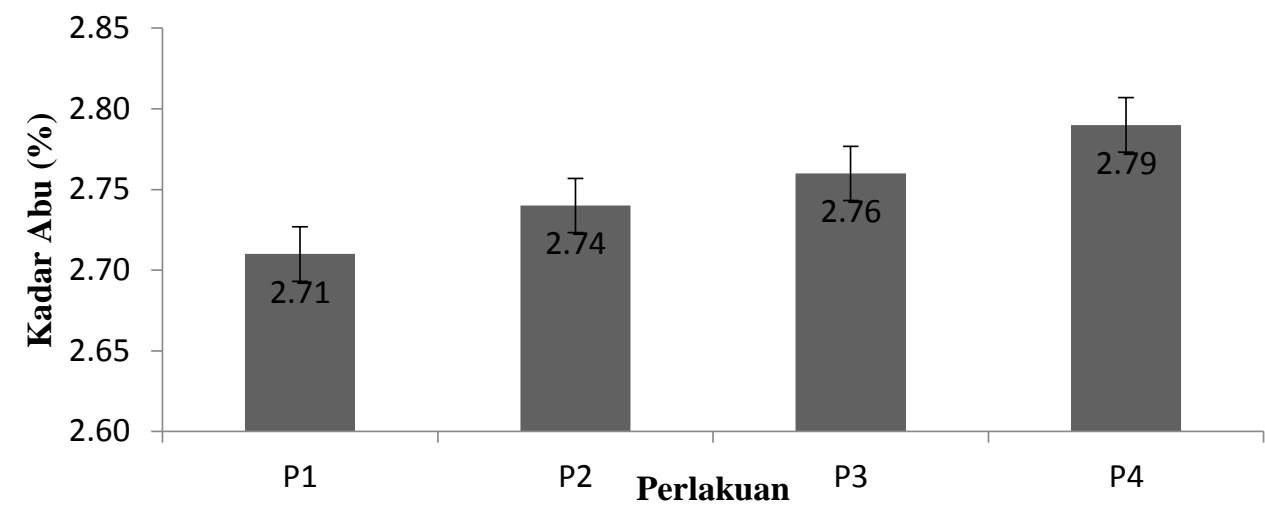

Keterangan:

$\mathrm{P} 1=$ Ampas kelapa 0 gram daging ayam 350 gram

$\mathrm{P} 2=$ Ampas kelapa 100 gram daging ayam 250 gram

P3 = Ampas kelapa 200 gram daging ayam 150 gram

P4 = Ampas kelapa 300 gram daging ayam 50 gram

Gambar 2. Hasil Uji kadar abu pada pembuatan abon ampas kelapa dengan penambahan daging ayam 
Berdasarkan uji BNT pada taraf $(\mathrm{P}>0,05)$ terlihat bahwa uji kadar abu pada abon ampas kelapa yang ditambahkan daging ayam, tanpa ampas kelapa dan 350 gram daging ayam berbeda tidak nyata terhadap jumlah abu yang dikandung oleh abon ampas kelapa dari setiap perlakuan.

Tabel 2. Analisis Sidik Ragam Uji kadar abu pada pembuatan abon ampas kelapa dengan penambahan daging ayam

\begin{tabular}{cccccc} 
Sumber Keragaman & $J K$ & $D B$ & $K T$ & $F$ Hit & F Tabel \\
\hline Perlakuan & 0.010033 & 3 & 0.003344 & $0.007603^{\text {ns }}$ & 4.066181 \\
Galat & 3.519191 & 8 & 0.439899 & & \\
Total & 3.529224 & 11 & & \\
\hline \multicolumn{6}{c}{ Sumber: Data setelah diolah, 2021 } \\
Keterangan: (ns) berbeda tidak nyata &
\end{tabular}

\section{c. Kadar Lemak}

Hasil uji kadar lemak untuk abon ayam dengan penambahan daging ayam menunjukkan nilai antara 10,62 - 40,64\%. Perlakuan tertinggi kandungan lemak pada ampas kelapa 300 gram dengan penambahan daging ayam 50 gram yaitu 40,64\%. Tingginya kandungan lemak abon ampas kelapa ini disebabkan komposisi ampas kelapa yang kaya lemak sebanyak 38,24\% (Pravitasari, 2017) termasuk juga daging ayam sebesar $25 \%$ (Depkes,
1996) walaupun dalam proses pembuatan abon ampas kelapa ditambahkan minyak nabati sebagai sumber lemak dengan maksud untuk penumisan tetapi persentase jumlah minyak nabati yang ditambahkan tetap sama untuk setiap perlakuan. Menurut Winarno (1997), Semakin banyak minyak yang ditambahkan dalam proses pembuatan abon maka semakin tinggi juga kadar lemak yang dihasilkan.

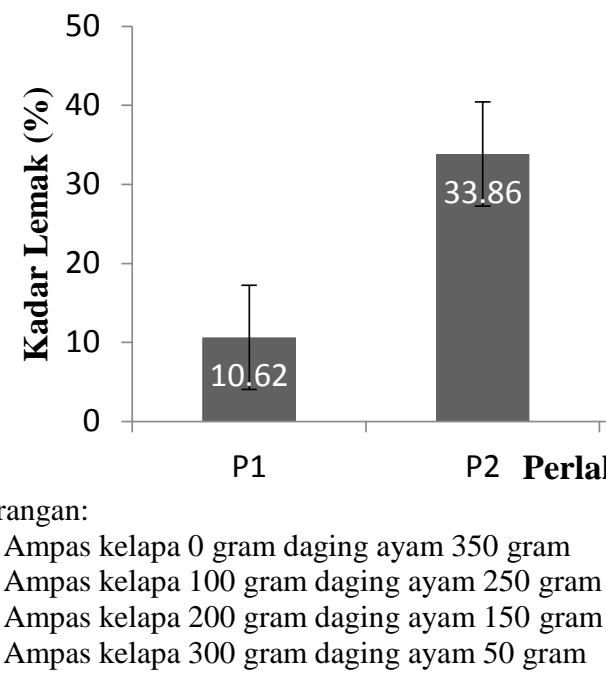

Gambar 3. Hasil Uji kadar lemak pada pembuatan abon ampas kelapa dengan penambahan daging ayam

Hasil analisis sidik ragam memperlihatkan bahwa perlakuan berbeda sangat nyata terhadap uji kadar lemak abon ampas kelapa dengan penambahan daging ayam, terbukti dari nilai $\mathrm{F}$ hitung lebih besar daripada $\mathrm{F}$ tabel
5\%. Hal ini menunjukkan bahwa perlakuan penambahan ampas kelapa dan daging ayam yang berbeda ternyata terdapat hasil berbeda sangat nyata terhadap jumlah kandungan lemak abon ampas kelapa.

Tabel 3. Analisis Sidik Ragam Uji kadar lemak pada pembuatan abon ampas kelapa dengan penambahan daging ayam

\begin{tabular}{clrrrr} 
Sumber Keragaman & \multicolumn{1}{l}{ JK } & DB & \multicolumn{1}{c}{ F Hit } & F Tabel \\
\hline Perlakuan & 1564.193 & 3 & 521,3976 & $443,5815^{* *}$ & 4,066181 \\
Galat & 9,403415 & 8 & 1,175427 & & \\
Total & 1573,596 & 11 & & & \\
\hline
\end{tabular}

Sumber: Data setelah diolah, 2021 Keterangan: (**) berbeda sangat nyata 


\section{d. Kadar Protein}

Hasil uji kadar lemak untuk abon ayam dengan penambahan daging ayam menunjukkan nilai antara $10,64-25,03 \%$. Perlakuan tertinggi kandungan lemak pada ampas kelapa 0 gram dengan penambahan daging ayam 350 gram yaitu 25,03\%. Perlakuan terendah kadar protein ada pada ampas kelapa 300 gram dan 50 gram daging ayam. Sementara komposisi protein bahan untuk ampas kelapa dan daging ayam adalah 5,78\% (Pravitasari, 2017) dan 18,6\% (Stadelman, 1988). Oleh karena itu semakin banyak penambahan daging ayam maka kadar protein semakin tinggi.

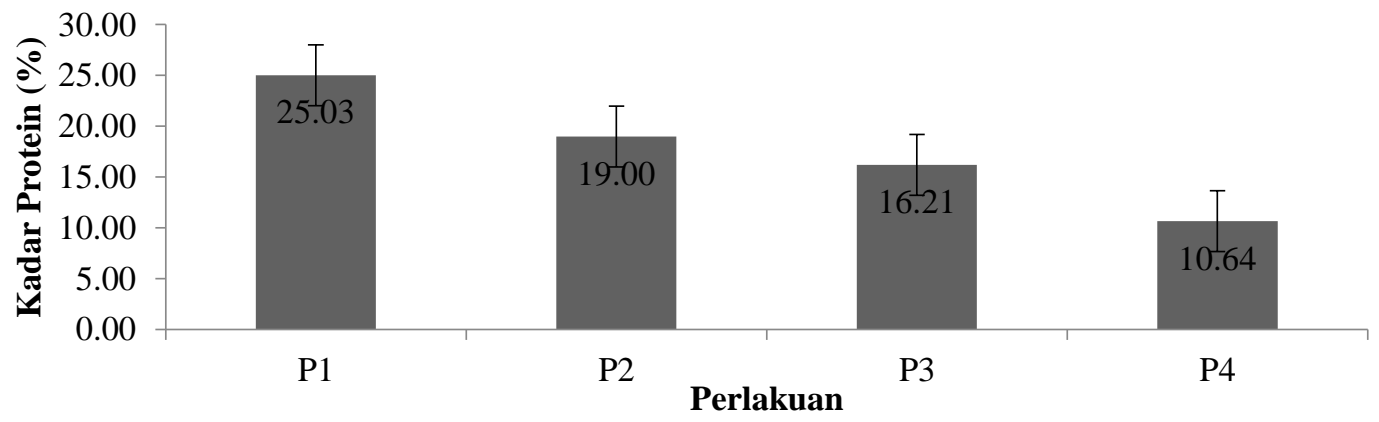

Keterangan:

$\mathrm{P} 1$ = Ampas kelapa 0 gram daging ayam 350 gram

$\mathrm{P} 2=$ Ampas kelapa $100 \mathrm{gram}$ daging ayam $250 \mathrm{gram}$

P3 = Ampas kelapa 200 gram daging ayam $150 \mathrm{gram}$

P4 = Ampas kelapa 300 gram daging ayam 50 gram

Gambar 4. Hasil Uji kadar protein pada pembuatan abon ampas kelapa dengan penambahan daging ayam

Tabel 4. Analisis Sidik Ragam Uji kadar lemak pada pembuatan abon ampas kelapa dengan penambahan daging ayam

\begin{tabular}{ccrrrr}
\hline Sumber Keragamanan & $J K$ & $D B$ & \multicolumn{1}{c}{ KT } & F Hit & F Tabel \\
\hline Perlakuan & 322,45204 & 3 & 107,484 & $67,0817^{* *}$ & 4,066181 \\
Galat & 12,818281 & 8 & 1,602285 & & \\
Total & 335,27032 & 11 & & & \\
\hline
\end{tabular}

\section{Sumber: Data setelah diolah, 2021}

Keterangan: $(* *)$ berbeda sangat nyata

Hasil analisis sidik ragam memperlihatkan bahwa perlakuan berbeda sangat nyata terhadap uji kadar protein abon ampas kelapa dengan penambahan daging ayam, terbukti dari nilai $\mathrm{F}$ hitung lebih besar daripada $\mathrm{F}$

\section{e. Kadar Karbohidrat}

Pada uji karbohidrat dapat menghasilkan nilai pada perlakuan ampas kelap 0 gram dan daging ayam 350 gram dapat menghasilkan karbohidrat sebanyak $47.97 \%$ dan pada perlakuan kedua ampas kelapa 100 gram dan daging ayam 250 gram menghasilkan nilai karbohidrat sebanyak $31.59 \%$ kemudian pada perlakuan ketiga dengan ampas kelapa 200 gram dan daging ayam 150 gram dapat menghasilkan $35.91 \%$ dan yang terakhir perlakuan keempat dengan ampas kelapa 300 gram dan daging ayam 50 gram dapat menghasilkan $36.01 \%$, hal ini menunjukan tabel 5\%. Hal ini menunjukkan bahwa perlakuan penambahan ampas kelapa dan daging ayam yang berbeda ternyata terdapat hasil berbeda sangat nyata terhadap jumlah kandungan protein abon ampas kelapa.

bahwa hasil uji karbohidrat pada abon ampas kelapa sudah memenuhi SNI abon daging yaitu dengan nilai karbohidrat 59,3 gram. Kadar karbohidrat bahan pangan akan bertolak belakang dengan komposisi Kimia lain, semakin rendah lemak suatu bahan pangan maka kadar karbohidrat akan semakin tinggi. Hal tersebut sesuai dengan (Widianto, 2002) yang menyatakan bahwa penyebab tingginya karbohidrat pada abon dimungkinkan karena penambahan gula merah dan santan kelapa dengan komposisi yang kurang tepat. 


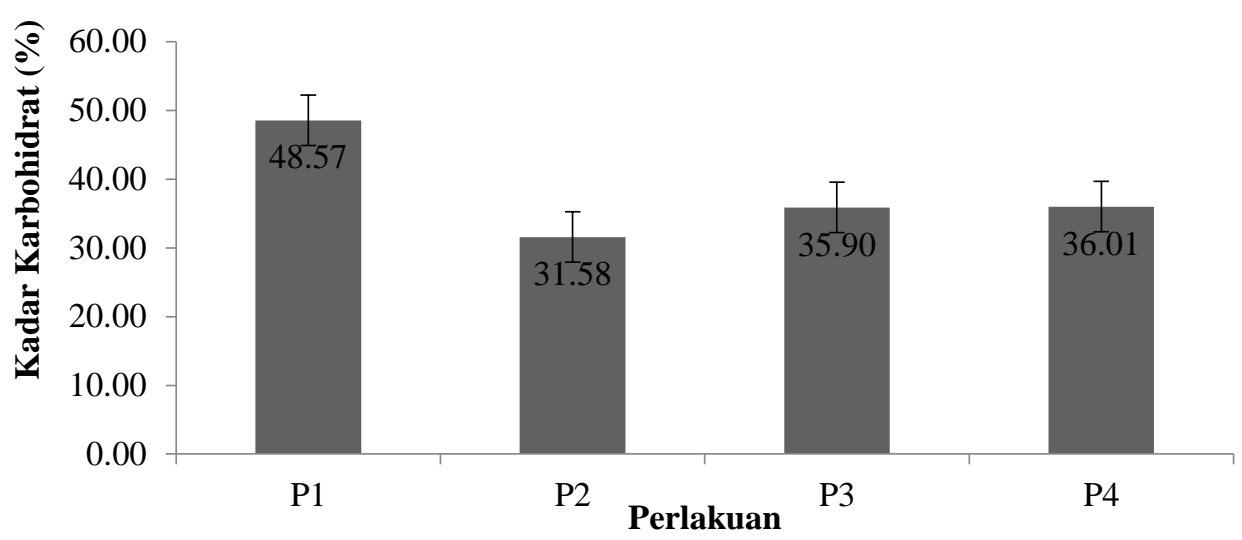

Keterangan:

$\mathrm{P} 1=$ Ampas kelapa 0 gram daging ayam 350 gram

$\mathrm{P} 2$ = Ampas kelapa 100 gram daging ayam 250 gram

P3 = Ampas kelapa 200 gram daging ayam 150 gram

$\mathrm{P} 4=$ Ampas kelapa 300 gram daging ayam 50 gram

Gambar 5. Hasil Uji kadar karbohidrat pada pembuatan abon ampas kelapa dengan penambahan daging ayam

2. Uji Organoleptik

a. warna

Hasil perhitungan uji organoleptik warna abon ampas kelapa dapat terlihat nilai dari keempat perlakuan yang memiliki rata-rata nilai lebih tinggi adalah perlakuan dengan daging ayam 150 gram dan ampas kelapa 200 gram dengan rata-rata 3.61 (suka) disusul pada perlakuan dengan daging ayam 250 gram dan ampas kelapa 100 gram dengan rata-rata 3.59 (suka) dan pada perlakuan dengan daging ayam 50 gram dan ampas kelapa 300 gram dengan rata-rata 3.36 (agak suka) sedangkan yang terendah terdapat pada perlakuan satu dengan daging ayam 350 gram dan ampas kelapa 0 gram dengan rata-rata mencapai 3.35 (agak suka). Warna abon ampas kelapa berwarna coklat. Warna coklat yang dihasilkan dari abon ampas kelapa enak dipandang mata, hal ini dikarenakan warna pada makanan merupakan salah satu faktor yang mempengaruhi daya terhadap makanan yang disajikan. Mutu bahan pangan pada umumnya tergantung pada faktor cita rasa, warna, tekstur, dan nilai gizi (Hamka dan Zainal, 2017). Warna merupakan kesan pertama yang muncul dan dinilai oleh panelis. Menurut Winarno (2004), warna merupakan parameter organoleptik yang paling pertama dalam penyajian. Menurut Apriliyanti (2010), menambahkan warna adalah atribut kualitas yang paling penting. Bersama-sama dengan tekstur dan rasa, warna berperan dalam penentuan tingkat penerimaan konsumen terhadap suatu produk, meskipun produk tersebut bernilai gizi tinggi, rasa enak dan tekstur baik namun jika warna tidak menarik maka akan menyebabkan produk tersebut kurang diminati.

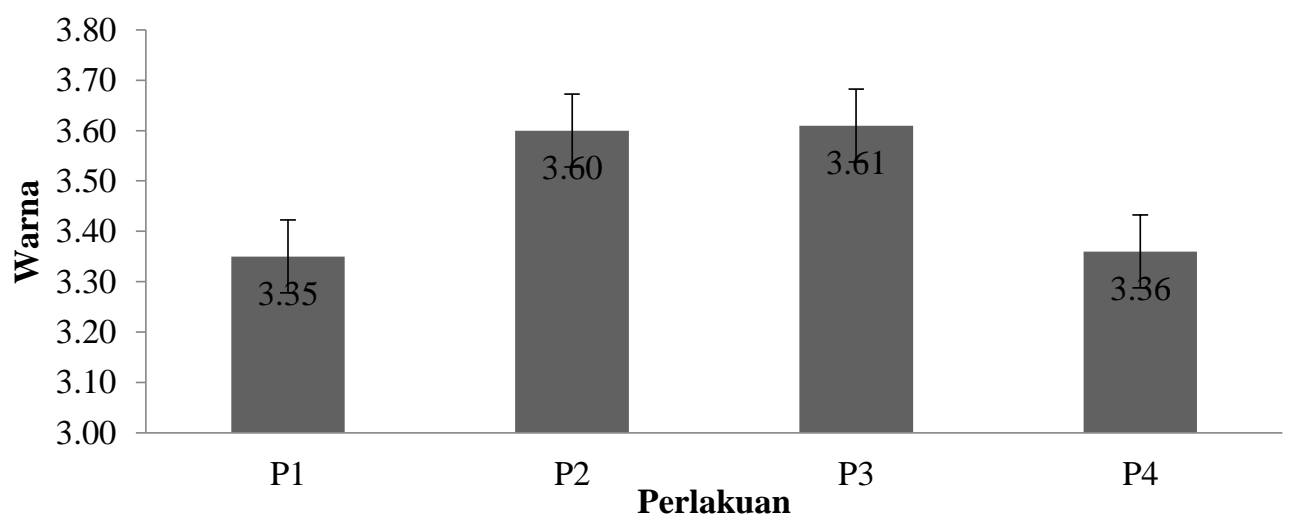

Keterangan:

$\mathrm{P} 1=$ Ampas kelapa 0 gram daging ayam 350 gram

$\mathrm{P} 2=$ Ampas kelapa 100 gram daging ayam 250 gram

P3 = Ampas kelapa 200 gram daging ayam 150 gram

$\mathrm{P} 4=$ Ampas kelapa 300 gram daging ayam 50 gram

Gambar 6. Hasil Uji organoleptik terhadap warna pada pembuatan abon ampas kelapa dengan penambahan daging ayam 
Berdasarkan uji BNT pada taraf $(\mathrm{P}>0,05)$ pada table 5, terlihat bahwa uji organoleptic terhadap warna pada abon ampas kelapa yang ditambahkan daging ayam, tanpa ampas kelapa dan 350 gram daging ayam berbeda tidak nyata terhadap tingkat kesukaan panelis abon ampas kelapa dari setiap perlakuan.

Tabel 5. Analisis Sidik Ragam Uji organoleptik terhadap warna pada pembuatan abon ampas kelapa dengan penambahan daging ayam

\begin{tabular}{crrrrr}
\hline Sumber Keragaman & \multicolumn{1}{c}{$J K$} & $D B$ & \multicolumn{1}{c}{ KT } & F Hit & F Tabel \\
\hline Perlakuan & 0,1930667 & 3 & 0,064356 & $0,706686^{\mathrm{ns}}$ & 4,066181 \\
Galat & 0,7285333 & 8 & 0,091067 & & \\
Total & 0,9216 & 11 & & & \\
\hline
\end{tabular}

Sumber: Data setelah diolah, 2021

Keterangan : (ns) berbeda tidak nyata

\section{b. Aroma}

Hasil perhitungan uji organoleptik aroma abon ampas kelapa dapat diketahui nilai dari keempat perlakuan yang memiliki rata - rata nilai lebih tinggi adalah perlakuan dengan daging ayam 150 gram dan ampas kelapa 200 gram dengan rata-rata 3.80 (suka) disusul pada perlakuan dengan daging ayam 50 gram dan ampas kelapa 300 gram dengan rata-rata 3.76 (suka) dan pada perlakuan dengan daging ayam 250 gram dan ampas kelapa 100 gram dengan rata-rata 3.57 (suka) sedangkan yang terendah terdapat pada perlakuan dengan daging ayam 350 gram dan ampas kelapa 0 gram dengan ratarata mencapai 3.20 (agak suka). Pada perlakuan yang memiliki nilai aroma terendah dikarenakan aroma pada abon ampas kelapa cenderung masih terasa aroma pada daging ayam. Sejalan dengan pendapat Winarno (2004) bahwa pada umumnya aroma yang diterima oleh hidung dan otak lebih banyak merupakan berbagai ramuan atau campuran empat aroma utama yaitu harum, asam, tengik dan hangus. Aroma merupakan salah satu parameter dalam pengujian sifat sensoris (organoleptik) dengan menggunakan indra penciuman. Aroma dapat diterima apabila bahan yang dihasilkan mempunyai aroma spesifik yang dihasilkan dengan penciuman (Lamusu, 2015).

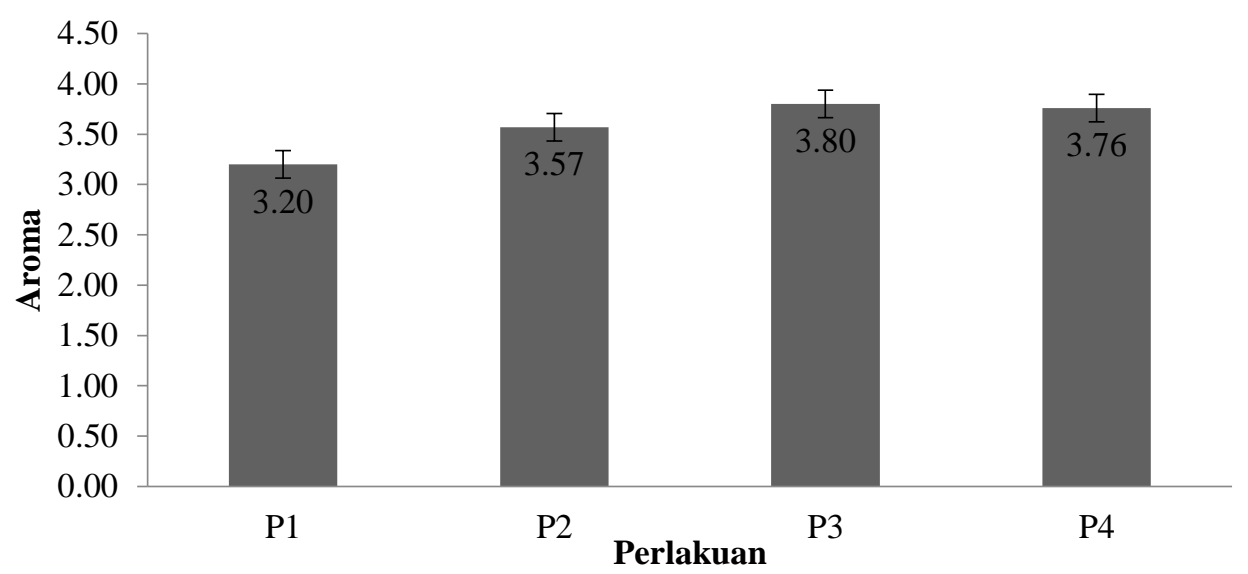

Keterangan:

$\mathrm{P} 1=$ Ampas kelapa 0 gram daging ayam 350 gram

$\mathrm{P} 2=$ Ampas kelapa 100 gram daging ayam 250 gram

P3 = Ampas kelapa 200 gram daging ayam 150 gram

$\mathrm{P} 4$ = Ampas kelapa 300 gram daging ayam 50 gram

Gambar 7. Hasil Uji organoleptik terhadap warna pada pembuatan abon ampas kelapa dengan penambahan daging ayam

Hasil analisis sidik ragam table 6, memperlihatkan bahwa perlakuan berbeda nyata terhadap uji organoleptik terhadap aroma abon ampas kelapa dengan penambahan daging ayam, terbukti dari nilai $\mathrm{F}$ hitung lebih besar daripada $\mathrm{F}$ tabel 5\%. Hal ini menunjukkan bahwa perlakuan penambahan ampas kelapa dan daging ayam yang berbeda ternyata terdapat hasil berbeda nyata terhadap tingkat kesukaan panelis produk abon ampas kelapa.

Tabel 6. Analisis Sidik Ragam Uji organoleptik terhadap aroma pada pembuatan abon ampas kelapa dengan penambahan daging ayam 


\begin{tabular}{crrrrr}
\hline Sumber Keragaman & \multicolumn{1}{c}{$J K$} & \multicolumn{1}{c}{$D B$} & \multicolumn{1}{c}{ KT } & \multicolumn{1}{c}{ F Hit } & F Tabel \\
\hline Perlakuan & 0,6756 & 3 & 0,2252 & $8,617347\left(^{*}\right)$ & 4,066181 \\
Galat & 0,2090667 & 8 & 0,026133 & & \\
Total & 0,8846667 & 11 & & & \\
\hline
\end{tabular}

Sumber: Data setelah diolah, 2021

Keterangan: $(*)$ berbeda nyata

c. Rasa

Hasil uji organoleptik menunjukan nilai rata - rata kesukaan terhadap rasa yang paling tinggi adalah perlakuan dengan daging ayam 150 gram dan ampas kelapa 200 gram dengan rata - rata 3.67 (suka) disusul pada perlakuan dengan daging ayam 250 gram dan ampas kelapa 100 gram dengan rata - rata 3.65 (suka) dan pada perlakuan dengan daging ayam 50 gram dan ampas kelapa 300 gram dengan rata - rata 3.59 (suka) sedangkan yang terendah terdapat pada perlakuan dengan daging ayam 350 gram dan ampas kelapa 0 gram dengan rata - rata mencapai 3.32 (agak suka). Rasa yang terdapat pada abon ampas kelapa dengan konsentrasi ampas kelapa yang berbeda memiliki rasa yang banyak dinikmati. Dengan cita rasa yang khas dari kelapa sehingga pada uji organoleptik rasa memiliki nilai tertinggi pada perlakuan ampas kelapa 200 gram dan daging ayam 150 gram. Cita rasa dapat dipengaruhi oleh pengolahan dimana proses pengolahan mengakibatkan degradasi penyusun cita rasa dan sifat fisik bahan makanan. Semakin lama waktu pengolahan akan merusak citarasa dan tekstur makanan tersebut. Makanan yang memiliki cita rasa yang tinggi adalah makanan yang menarik, menebarkan bau yang sedap dan memberikan rasa yang lezat. Pada proses pemanasan yang berlebihan dapat terjadi reaksi yang mengakibatkan cita rasa terlalu matang atau overcooked yang tidak disukai konsumen (Dian, et al., 2016).

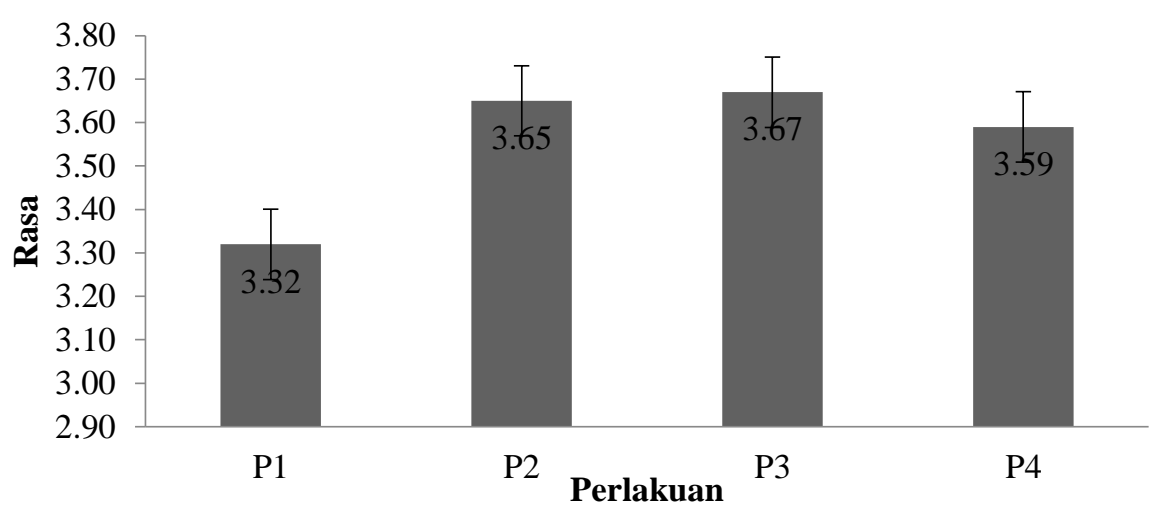

Keterangan:

$\mathrm{P} 1$ = Ampas kelapa 0 gram daging ayam 350 gram

$\mathrm{P} 2$ = Ampas kelapa 100 gram daging ayam 250 gram

P3 = Ampas kelapa 200 gram daging ayam 150 gram

P4 = Ampas kelapa 300 gram daging ayam 50 gram

Gambar 8. Hasil Uji organoleptik terhadap rasa pada pembuatan abon ampas kelapa dengan penambahan daging ayam

Tabel 7. Analisis Sidik Ragam Uji organoleptik terhadap rasa pada pembuatan abon ampas kelapa dengan penambahan daging ayam

\begin{tabular}{crrrrr}
\hline Sumber Keragaman & \multicolumn{1}{c}{ JK } & DB & \multicolumn{1}{c}{ KT } & F Hit & F Tabel \\
\hline Perlakuan & 0,2313 & 3 & 0,0771 & $1,125547^{\text {ns }}$ & 4,066181 \\
Galat & 0,548 & 8 & 0,0685 & & \\
Total & 0,7793 & 11 & & & \\
\hline
\end{tabular}

Sumber: Data setelah diolah, 2021

Keterangan: (ns) berbeda tidak nyata

Berdasarkan uji BNT pada taraf $(\mathrm{P}>0,05)$ pada table 7 , terlihat bahwa uji organoleptik terhadap rasa pada abon ampas kelapa yang ditambahkan daging ayam, tanpa ampas kelapa dan 350 gram daging ayam berbeda tidak nyata terhadap tingkat kesukaan panelis abon ampas kelapa dari setiap perlakuan. 


\section{d. Tekstur}

Hasil uji organoleptik menunjukan nilai ratarata kesukaan terhadap tekstur yang paling tinggi adalah perlakuan dengan daging ayam 150 gram dan ampas kelapa 200 gram dengan rata-rata 3.85 (suka) disusul pada perlakuan daging ayam 50 gram dan ampas kelapa 300 gram dengan rata-rata 3.76 (suka) dan pada perlakuan dengan daging ayam 250 gram dan ampas kelapa 100 gram dengan rata-rata 3.45 (agak suka) sedangkan yang terendah terdapat pada perlakuan dengan daging ayam 350 gram dan amapa 0 gram dengan rata - rata mencapai 2.49 (Tidak suka). Bila nilai tingkat kesukaan terhadap tekstur tinggi maka dapat dikatakan abon ampas kelapa disukai dan sebaliknya jika tingkat kesukaan rendah, maka belum dikatakan disukai dalam hal rasa. Pengujian tekstur pada abon tersebut sangat penting dilakukan karena tekstur merupakan hal yang harus disesuaikan dengan jenis suatu produk. Tekstur dapat mempengaruhi rasa yang ditimbulkan oleh makanan (Lamusu, 2015).

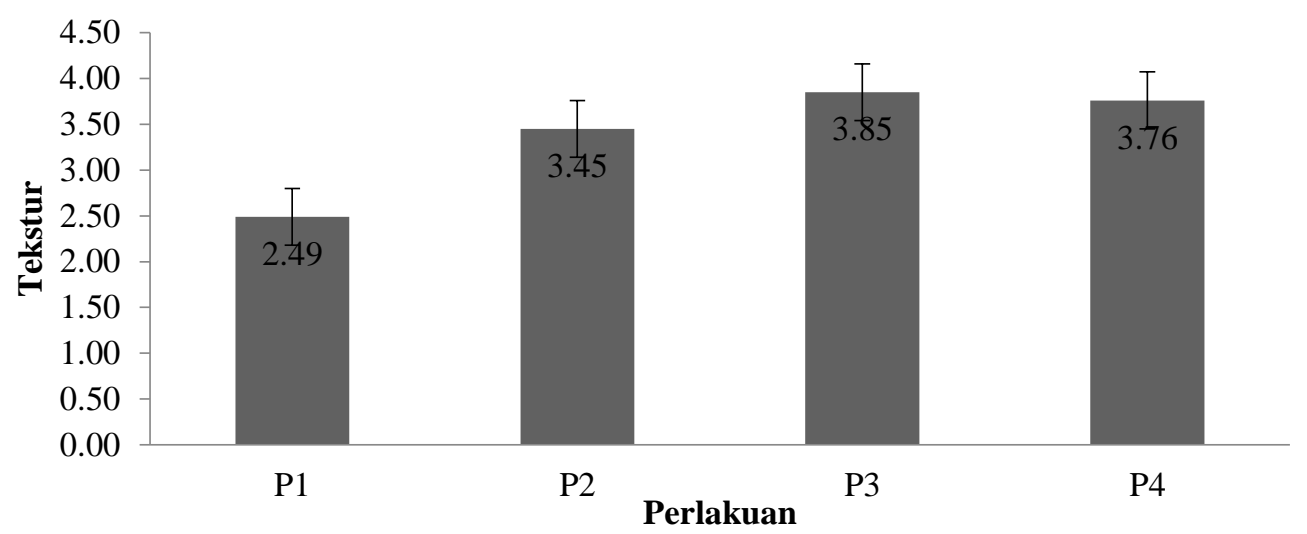

Keterangan:

$\mathrm{P} 1$ = Ampas kelapa 0 gram daging ayam 350 gram

$\mathrm{P} 2=$ Ampas kelapa 100 gram daging ayam 250 gram

P3 = Ampas kelapa 200 gram daging ayam 150 gram

P4 = Ampas kelapa 300 gram daging ayam 50 gram

Gambar 9. Hasil Uji organoleptik terhadap tekstur pada pembuatan abon ampas kelapa dengan penambahan daging ayam

Tabel 8. Analisis Sidik Ragam Uji organoleptik terhadap tekstur pada pembuatan abon ampas kelapa dengan penambahan daging ayam

\begin{tabular}{clrrrrr}
\hline Sumber Keragaman & $J K$ & $D B$ & $K T$ & F Hit & F Tabel \\
\hline Perlakuan & 3,4788 & 3 & 1,1596 & $107,3704^{* * *}$ & 4,066181 \\
Galat & 0,0864 & 8 & 0,0108 & & \\
Total & 3,5652 & 11 & & & \\
\hline
\end{tabular}

Sumber: Data setelah diolah, 2021

Keterangan: (**)berbeda sangat nyata

Hasil analisis sidik ragam memperlihatkan bahwa perlakuan berbeda sangat nyata terhadap uji organoleptik terhadap tekstur abon ampas kelapa dengan penambahan daging ayam, terbukti dari nilai $\mathrm{F}$ hitung lebih besar daripada $\mathrm{F}$ tabel $5 \%$. Hal ini menunjukkan bahwa perlakuan penambahan ampas kelapa dan daging ayam yang berbeda ternyata terdapat hasil berbeda sangat nyata terhadap tingkat kesukaan panelis untuk rasa abon ampas kelapa

\section{KESIMPULAN}

Hasil uji kimia pembuatan abon menggunakan ampas kelapa sebagai bahan pengisi memiliki kandungan air yang tinggi pada perlakuan dengan daging ayam 350 gram dan ampas kelapa 0 gram dengan nilai kadar air $13.07 \%$ tidak sesuai syarat mutu SNI abon. Kadar abu dan kadar lemak yang tertinggi pada perlakuan dengan daging ayam 50 gram dan ampas kelapa 300 gram dengan nilai $2.79 \%$ dan $40,64 \%$. sementara kadar protein dan karbohidrat yang tertinggi pada perlakuan dengan daging ayam 0 gram dan ampas kelapa 350 gram dengan nilai rata-rata $25.63 \%$ dan $47,97 \%$.

Hasil uji organoleptik terhadap pembuatan abon menggunakan ampas kelapa sebagai bahan pengisi dengan penambahan daging ayam memperlihatkan bahwa 
warna, aroma, rasa dan tekstur terhadap kesukaan panelis menunjukan angka suka yaitu dengan rata - rata nilai tertinggi pada perlakuan dengan daging ayam 150 gram dan ampas kelapa 200 gram dengan nilai rata-rata 3.61(suka), aroma 3.80 (suka), rasa 3.67(suka) dan pada tekstur 3.85(suka).

\section{DAFTAR PUSTAKA}

Andarwulan N., Feri K., dan Dian H., 2011. Analisis Pangan. Dian Rakyat. Jakarta.

Apriliyanti, Tina. 2010. Kajian Sifat Fisikokimia dan Sensori Tepung Ubi Jalar Ungu Dengan Variasi Proses Pengeringan. Skripsi. Fakultas Pertanian Universitas Sebelas Maret Surakarta.

Christian, J.H.B. (1980). Reduced Water Activity. Dalam : Silliter, J.H.; R.P. Elliot; A.C.B. Parker and F.L. Bryan. Microbiol Ecology of Foods. International Journal of Food Sciences and Nutrition, 1 : 70-91.

Dian Novita Sari, A.D. Murtado, Mukhtarudin Muchsiri. 2016. Mempelajari Berbagai Suhu Awal Perebusan
Terhadap Kehilangan Protein Daging Sapi Bagian Has Dalam. Jurnal Edible. Vol 5 No. 1. pp 44-48.

Hamka dan Zainal Pain Geroda. 2017. Pengaruh Lama Perendaman dan Perbedaan Metode Pengeringan pada Pembuatan Tepung Ampas Kelapa. Buletin Loupe. Vol 14. No.2. pp 1-5.

Hutsoit, G.F. 1988. Ampas Kelapa: Dari Tempe Bongkrek ke Pemanis. Majalah Perusahaan Gula Pasuruan. Pusat Penelitian Perkebunan Gula Indonesia 24 (3):19-24.

Lamusu, Darni. 2015. Uji Organoleptik Jalangkote Ubi Jalar Ungu (Ipomoea batatas L) Sebagai Upaya Diversifikasi Pangan. Jurnal Pengolahan Pangan. Vol 3 No.1. pp 9-15.

Pravitasari, Gista Arum. 2017. Pengaruh Penambahan Fermentasi Ampas Kelapa (Cocos Nucifera L.) Oleh Ragi Tempe Sebagai Campuran Pakan Terhadap Bobot, Rasio Pakan, dan Income Over Feed Cost Ayam Kampung (Gallus Gallus Domesticus). Skripsi Thesis, Sanata Dharma University. 
$-260-$ 